\title{
Role of renal nerves for the expression of renin in adult rat kidney
}

\author{
STEPHAN HOLMER, BETTINA RINNE, KAI-UWE ECKARDT, MICHEL LE HIR, \\ KARIN SCHRICKER, BRIGITTE KAISSLING, GÜNTER RIEGGER, AND ARMIN KURTZ \\ Klinik und Poliklinik für Innere Medizin II and Physiologisches Institut, Universität Regensburg, \\ D-93040 Regensburg, Germany; and Anatomisches Institut der Universität Zürich, \\ CH-8044 Zurich, Switzerland
}

\begin{abstract}
Holmer, Stephan, Bettina Rinne, Kai-Uwe Eckardt, Michel Le Hir, Karin Schricker, Brigitte Kaissling, Günter Riegger, and Armin Kurtz. Role of renal nerves for the expression of renin in adult rat kidney. Am. J. Physiol. 266 (Renal Fluid Electrolyte Physiol. 35): F738-F745, 1994.Utilizing a combination of mechanical and chemical unilateral denervation, we have examined the relevance of renal innervation for the expression of renin in kidneys of adult rats. Renal denervation led to a reduction by $57 \pm 4 \%$ of renin-containing areas in denervated kidneys as quantitated by morphometry of kidney sections immunoreactive against a polyclonal antirenin antibody. Preprorenin mRNA content in the denervated kidneys fell to $46 \pm 7 \%$ of the contralateral innervated kidneys. Treatment of rats with the $\beta_{1}$-adrenoreceptor antagonist metoprolol $\left(100 \mathrm{mg} \cdot \mathrm{kg}^{-1} \cdot \mathrm{day}^{-1}\right)$ for 2 days decreased renal renin mRNA levels to $71 \%$ of control levels. Unilateral renal denervation led to a further decrease of renin mRNA levels also in metoprolol-treated animals to $60 \%$ of the values found in the contralateral kidneys. Hypotensive hemorrhage led to a 1.4-fold increase of renin mRNA in the kidneys of shamtreated animals. In unilaterally denervated rats renin mRNA increased to levels similar to those in sham-operated animals in both denervated and in contralateral innervated kidneys in response to bleeding. As a consequence, the ratio of abundance of renin mRNA in the denervated to the innervated kidneys rose to $86 \pm 7 \%$. Pretreatment of the animals with metoprolol, on the other hand, prevented the rise of renin mRNA in response to hypotensive hemorrhage. Our findings suggest that in the adult organism renal neural input significantly contributes to the expression of renin under basal conditions, while it appears to be of less importance for stimulation of renin gene expression by severe blood loss.
\end{abstract}

juxtaglomerular cells; adrenergic receptors; hemorrhage

IT IS WELL ESTABLISHED that renal nerves, in particular sympathetic fibers, play an important role in the regulation of renin secretion from the juxtaglomerular apparatus (12). Although supporting evidence is not convincing, it is likely that activation of specific renal sympathetic fibers may also be inhibitory for renin secretion (12); sympathetic nervous stimulation is considered to be a powerful stimulatory signal for renin secretion by activation of a $\beta_{1}$-adrenergic pathway (12, 15). However, less information is available about the role renal nerves play in modulating the intrarenal expression of renin. A recent study suggests that renal nerves mediate an increase of renin expression in response to ureteral ligation in newborn rats (6). Moreover, evidence has been obtained that renal nerves modulate kidney renin gene expression during the transition from fetal to newborn life in lambs (17). The information available about the relevance of renal nerves for renin gene expression in the adult organism is contradictory. Although chemical denervation was reported not to alter renin gene expression in rats (6), mechanical denervation was found to reduce renin mRNA levels in adult mice (21). In view of this unclear situation it appeared reasonable to us to examine the role of renal nerves for renin expression in adult rats with unilaterally denervated kidneys under basal conditions and under stimulation by hypotensive hemorrhage.

Our results suggest that $\sim 50 \%$ of the renin-expressing cells are under the control of neural input in nonstimulated conditions. Hypotensive hemorrhage led to increases of renin mRNA levels to similar levels in innervated and denervated kidneys, suggesting that renal innervation is not the major pathway for the activation of renin gene expression in response to this stimulus.

\section{MATERIALS AND METHODS}

Animals. Male Wistar rats weighing 200-250 g were used in this study. The animals had free access to standard laboratory $\operatorname{diet}$ (Altromin) and tap water.

Renal denervation. Animals were anesthetized with pentobarbital $(45 \mathrm{mg} / \mathrm{kg}$ ip). Left-sided renal denervation was performed according to the method of Bello-Reuss et al. (1). The abdominal wall was opened along the midline, and the left renal artery and vein were exposed by carefully retracting the adipose tissue and the peritoneum. Mechanical denervation was carried out using an operation microscope by sectioning any visible nerve fiber penetrating the renal hilum and by stripping the adventitia from the renal artery. To destroy any remaining nerve fibers, the artery was subsequently painted with a solution of $10 \%$ phenol in ethanol. After 5-min exposure to that solution the artery was washed with isotonic saline. In sham-operated animals, the left artery and vein were exposed as described above, but mechanical denervation and treatment with the phenol solution were omitted. The rats were closed and awakened within a few hours. In a previous study we had observed that neural markers (see below) disappeared 4 days after denervation (5). Therefore all the denervated rats used in this study were killed on the 5th day after denervation.

Treatment with $\beta_{1^{-}}$adrenoreceptor antagonist. The $\beta_{1^{-}}$ adrenoreceptor antagonist metoprolol succinate (Beloc, Astra Chem, Wedel, Germany) was administered orally $(50 \mathrm{mg} / \mathrm{kg}$; suspended in $1 \mathrm{ml}$ water) by gavage every $12 \mathrm{~h}$ for 2 days. Treatment with metoprolol succinate in animals with unilateral renal denervation was performed on the 4th and 5th day after denervation. For bleeding experiments animals were pretreated with metoprolol succinate for $48 \mathrm{~h}$, and a final dose of $50 \mathrm{mg} / \mathrm{kg}$ was administered $1 \mathrm{~h}$ before induction of hemorrhage as described below. 
Stimulation of renin expression by hemorrhage. We also used conscious animals to study the role of renal nerves for renin expression by hemorrhage, to avoid nonspecific activation of renal nerves and of the renin system by anesthesia (12). For induction of hemorrhagic anemia and hypotension a catheter was inserted into the left carotid artery under brief general anesthesia (methohexital, $100 \mathrm{mg} / \mathrm{kg}$ ) in six left-side denervated, four sham-operated, and four metoprolol-treated rats. The rats awakened within a few minutes after insertion of the catheter. Then approximately $4,3.5,3$, and $2.5 \mathrm{ml}$ of blood were subsequently drawn from the conscious animals via the catheter in 0.5 - to $1-\mathrm{ml}$ portions in hourly intervals and replaced with an equal volume of Ringer solution on the first, second, and fourth occasion and an equal volume of homologous plasma on the third occasion. During the experiment the animals were neither restrained nor sedated. For the volume exchange they were placed in a topless shoe box, and they were kept in the dark by covering the box with a few sheets of tissue paper. After each volume exchange the animals were returned to their cages with free access to laboratory diet and water. With this protocol the animals remained conscious and we did not observe obvious signs of excitation of the animals. The rats were killed $4 \mathrm{~h}$ after the last volume exchange. Mean arterial blood pressure was monitored in the animals by a Statham transducer connected to the arterial catheter before the first and fourth blood sampling and before animals were killed. Immediately after animals were killed by decapitation, blood was sampled from the carotid arteries for determination of hematocrit (microcentrifugation), and both kidneys were rapidly removed, weighed, cut in half, and frozen in liquid nitrogen for extraction of total RNA.

Fixation of the kidneys. For immunohistochemistry and morphological examination eight denervated, six shamoperated, and three untreated animals were perfusion fixed. The animals were anesthetized (by thiopentobarbital sodium, Trapanal; Byk Gulden, Germany; $100 \mathrm{mg} / \mathrm{kg}$ ip) and were fixed by vascular perfusion via the abdominal aorta with a buffered solution containing $2.5 \%$ paraformaldehyde and $0.1 \%$ glutaraldehyde, as described previously (5). For immunohistochemistry large slices across one-half of a kidney, comprising the cortex and all medullary zones, were shock frozen in liquid propane, and sections $5 \mu \mathrm{m}$ thick were cut in a cryostat. After three to four serial sections at least $150 \mu \mathrm{m}$ of the tissue were cut off, then a series of sections was made until at least seven slides were available per kidney. The serial sections, placed on one slide, were alternately stained for renin (using a polyclonal rabbit antiserum against rat renin, diluted 1:10,000), for detection of the neurotransmitter neuropeptide Y (NPY), using a polyclonal rabbit antiserum against NPY (Peninsula, Belmont, CA) diluted 1:200, and of acetylcholinesterase activity, using acetylcholine iodide as substrate according to Karnowsky (11). Binding sites of the primary antibodies were visualized with a fluorescein isothiocyanate-labeled swine anti-rabbit immunoglobulin $G$ antiserum, diluted $1: 100$ in phosphate-buffered saline. The sections were counterstained with Evans blue dye, 1\% in water.

The slides were coded and analyzed in a microscope (Polyvar, Reichart-Jung, Austria). First, the renin-positive areas were quantified. For that purpose the sections were studied by epifluorescence, at a magnification of $\times 250$ in the microscope. The microscopic image was superimposed by a square grid (20) via a drawing tube. The grid consisted of perpendicular lines with a spacing of $1 \mathrm{~mm}$. The distance of the lines seen in the microscope corresponded to a distance of $4.17 \mu \mathrm{m}$ in the tissue; the area covered by the grid on the tissue corresponded to 0.25 $\mathrm{mm}^{2}$. The total surface area of measurement per kidney was $18.4 \pm 1.68 \mathrm{~mm}^{2}($ mean $\pm \mathrm{SD})$, determined by the number of intersections falling onto the evaluated tissue area. Within this area all glomeruli with a vascular pole, defined by showing the contact of at least one glomerular arteriole with the glomerular hilum, were counted, and the number of reninpositive and renin-negative vascular poles was recorded. The total number of encountered vascular poles per evaluated area was $31.8+8.0$ (mean $\pm \mathrm{SD})$. Then the number of intersections of the grid falling on all renin-immunoreactive areas (including also renin-positive areas in arterioles distant from the vascular pole) and the surface density of renin-positive areas was calculated (20). The sum of the renin-positive areas measured per kidney, divided by the respective number of vascular poles, including those without visible immunoreactivity, indicates the mean area per vascular pole within the given kidney. This value was called the "renin index." After the quantitative evaluation, the parallel sections were scanned with high magnification for immunoreactivity for NPY and for acetylcholinesterase activity, to evaluate the presence of nerve fibers in the tissue.

Determination of preprorenin $m R N A$. Total RNA was extracted from kidney halves that were stored at $-70^{\circ} \mathrm{C}$, according to the protocol of Chirgwin et al. (3) by homogenization in $18 \mathrm{ml}$ of guanidine thiocyanate $(4 \mathrm{M})$ containing $0.5 \% \mathrm{~N}$ laurylsarcosinate, $10 \mathrm{mM}$ EDTA, $25 \mathrm{mM}$ sodium citrate, and $700 \mathrm{mM} \beta$-mercaptoethanol with a Polytron homogenizer and by subsequent purification on a cesium chloride gradient. To this end, the homogenate was layered onto a cushion of $5.7 \mathrm{M}$ cesium chloride and $100 \mathrm{mM}$ EDTA and centrifuged for $20 \mathrm{~h}$ at 33,000 revolutions per minute. After centrifugation, RNA pellets were resuspended in $300 \mu \mathrm{l}$ TE $[10 \mathrm{mM}$ tris(hydroxymethyl)aminomethane (Tris), pH 7.5, 1 mM EDTA] containing $0.1 \%$ sodium dodecyl sulfate (SDS), precipitated with $3 \mathrm{M}$ sodium acetate $(0.1 \mathrm{vol})$ and ethanol (3 vol), and stored at $-70^{\circ} \mathrm{C}$ before analysis. Renin mRNA was measured by ribonuclease (RNase) protection as described for erythropoietin mRNA (18). A preprorenin cRNA probe containing $296 \mathrm{bp}$ of exon I and II, generated from a pSP64 vector carrying a $P s t$ I-Kpn I restriction fragment of a rat preprorenin cDNA (2), was generated by transcription with SP6 RNA polymerase (Amersham International, Amersham, UK). Transcripts were continuously labeled with a $\left[{ }^{32} \mathrm{P}\right] \mathrm{GTP}(410 \mathrm{Ci} / \mathrm{mmol}$; Amersham International) and purified on a Sephadex G50 spun column. For hybridization, total kidney RNA was dissolved in a buffer containing $80 \%$ formamide, $40 \mathrm{mM}$ piperazine- $N, N^{\prime}$ bis(2-ethanesulfonic acid), $400 \mathrm{mM} \mathrm{NaCl}$, and $1 \mathrm{mM}$ ED'l'A, $\mathrm{pH}$ 8. Twenty micrograms of RNA were hybridized in a total volume of $50 \mu \mathrm{l}$ at $60^{\circ} \mathrm{C}$ for $12 \mathrm{~h}$ with $5 \times 10^{5}$ counts per minute (cpm) of radiolabeled renin probe. RNase digestion with RNase A and T1 was carried out at $20^{\circ} \mathrm{C}$ for $30 \mathrm{~min}$ and terminated by incubation with proteinase $\mathrm{K}(0.1 \mathrm{mg} / \mathrm{ml})$ and SDS $(0.4 \%)$ at $37^{\circ} \mathrm{C}$ for $30 \mathrm{~min}$. Protected renin mRNA fragments were purified by phenol-chloroform extraction, ethanol precipitation, and subsequent electrophoresis on a denaturing $10 \%$ polyacrylamide gel. After autoradiography of the dried gel at $-70^{\circ} \mathrm{C}$ for $1-2$ days, bands representing protected renin mRNA fragments were excised from the gel, and radioactivity was counted with a liquid scintillation counter (1500 Tri-Carb, Packard Instrument, Downers Grove, IL). The number of counts per minute obtained from each sample of total kidney RNA was expressed relative to an external renin mRNA standard included in each hybridization consisting of $20 \mu \mathrm{g}$ pooled RNA extracted from kidneys of untreated control animals. The linearity of the assay was tested by analyzing $5,10,20$, and $40 \mu \mathrm{g}$ of the RNA pool, where we found a linear relationship between the amount of RNA used and the ${ }^{32} \mathrm{P}$ radioactivity of the bands excised from the gel $\left({ }^{32} \mathrm{P}\right.$ radioactivity $=32+19 \mathrm{cpm} / \mu \mathrm{g} \mathrm{RNA} ; r^{2}=1.0$ ). 


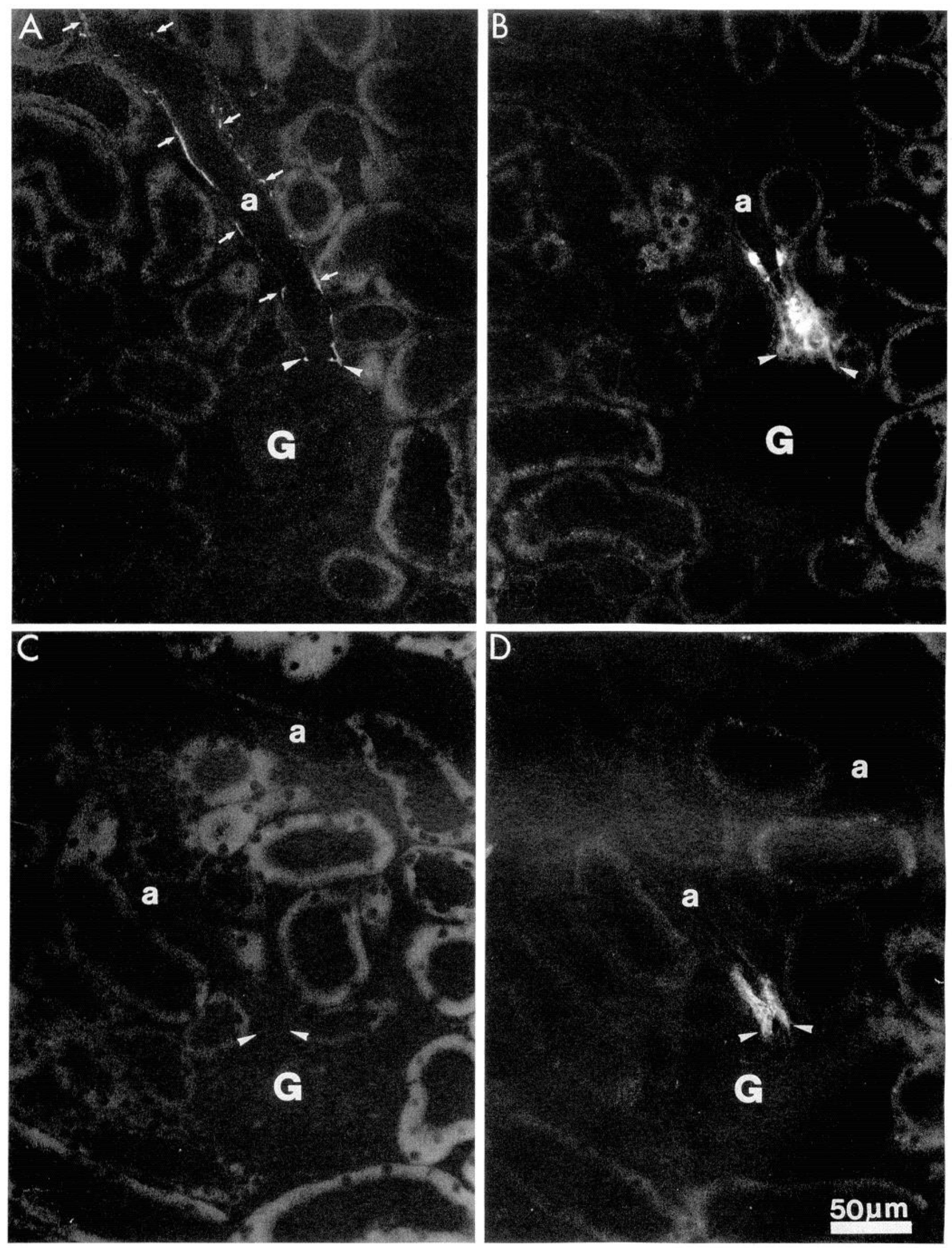

Fig. 1. Immunofluorescence for demonstration of nerve fibers $(A$ and $C)$ and renin $(B$ and $D)$ in consecutive cryostat sections of rat kidney. $A$ and $B$, right innervated kidney; $C$ and $D$, left denervated kidney of same animal. Arrowheads indicate the vascular pole of glomeruli; immunostaining of renin is evident in the wall of the afferent arteriole by the bright fluorescence. Short arrows in $A$ point to some stained nerve fibers along the afferent arteriole; such fibers are absent in the denervated kidney $(C)$. $A$ and $C$ immunostained with an antiserum against neuropeptide Y (NPY), $B$ and $D$ with an antiserum against rat renin. Binding of the antiserum has been visualized by a fluorescein isothiocyanatelabeled secondary antibody. G, glomerulus; a, afferent arteriole. Magnification $\times 300$; bar $=50 \mu \mathrm{m}$. 

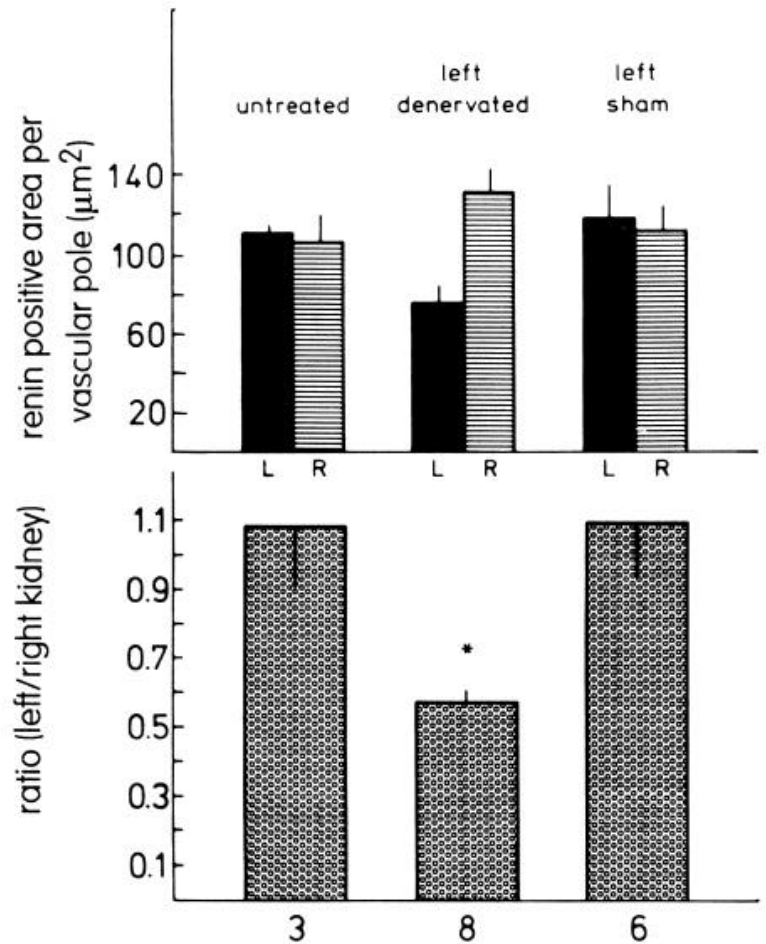

Fig. 2. Top: renin immunoreactive areas per vascular pole (i.e., renin index) in rat kidney sections from untreated, sham-operated, and left-side-denervated rats as estimated from morphometry. L and R, left and right kidneys. Bottom: ratio of renin immunoreactive area per vascular pole between left and right kidneys of individual animals of the different groups. Data are means $\pm \mathrm{SE}$; no. of animals is given at bottom of figure. ${ }^{*} P<0.01$ vs. 1.0 .

Determination of actin $\mathrm{mRNA}$. The abundance of rat cytoplasmic $\beta$-actin mRNA in total RNA isolated from the kidneys was determined by RNase protection assay exactly as described for preprorenin. An actin cRNA probe containing the 76-nucleotide first exon and $\sim 200$ bp of surrounding sequence was generated by transcription with SP6 polymerase from a pAM19 vector carrying an Ava I/Hind III restriction fragment of actin cDNA (18). For one assay $2.5 \mu \mathrm{g}$ RNA were hybridized under the conditions described for the determination of renin mRNA.

Statistics. Student's paired $t$ test and analysis of variance were used for intra- and interindividual comparisons.

\section{RESULTS}

Unilateral renal denervation was accomplished by a combination of chemical and mechanical procedures. The effectiveness of the renal denervation was assessed by monitoring the disappearance of neurotransmitters in the kidney, such as NPY, and of acetylcholinesterase. Figure 1 shows representative kidney sections of a denervated (Fig. 1C) and a contralateral innervated kidney (Fig. 1A) stained for NPY 5 days after denervation. NPY and the respective enzyme had disappeared at this time point, which was therefore chosen for further examination of renin expression.

Figure 1 also shows a typical distribution of immunoreactive renin in sections from the innervated (Fig. $1 B$ ) and denervated (Fig. $1 D$ ) kidney 5 days after denervation. Already on a first view there appear to be fewer areas immunoreactive for renin in the denervated com- pared with the innervated kidney. For a more quantitative comparison kidney sections from eight rats with unilateral denervation, from six sham-operated rats, and from three untreated rats were analyzed by computer-assisted morphometry. As shown in Fig. 2, the renin-positive area in the kidney sections of untreated animals was $111 \pm 3 \mu \mathrm{m}^{2}$ (mean $\pm \mathrm{SE}$ ) per glomerular vascular pole; moreover, there was no difference between right and left kidneys. Very similar results were obtained with animals in which the left kidney was sham denervated. This treatment did not influence the distribution of renin in the left compared with the right kidney $\left(118 \pm 18\right.$ vs. $\left.111 \pm 12 \mu \mathrm{m}^{2}\right)$ (Fig. 2 , top $)$. In denervated kidneys, however, renin-positive areas decreased to $75 \pm 9 \mu \mathrm{m}^{2}(P<0.01$ vs. contralateral kidneys), whereas the expression in the contralateral innervated kidney tended to increase but was not significantly different from control kidneys $\left(131 \pm 13 \mu \mathrm{m}^{2}\right)$. In summary, the ratio of renin-positive areas between left and right kidney decreased from $1.08 \pm 0.17$ in normal rats and $1.09 \pm 0.16$ in sham-denervated rats to $0.58 \pm$ 0.04 in denervated animals (Fig. 2 , bottom $)(P<0.01$, denervated vs. sham-denervated animals).

Specimens of the kidneys used for immunohistochemistry were further processed for analysis of the abundance of renin mRNA in total RNA. For standardization, a pool of renal RNA from the left kidneys of seven normal rats was created. Before pooling, renin mRNA level was determined separately in each kidney. As shown in Fig. 3 there was some interindividual variation in the abundance of renin mRNA, with a coefficient of variation of $15 \%$. When paired kidneys of untreated animals were investigated, intraindividual differences in renin mRNA between the right and left kidneys were

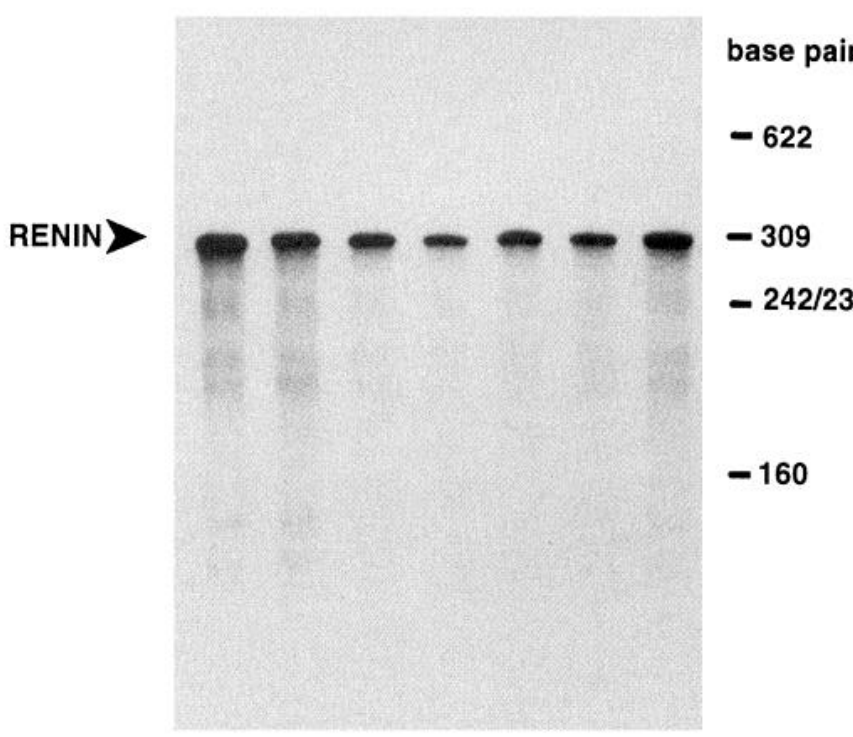

Fig. 3. Autoradiograph of a ribonuclease (RNase) protection assay for rat renin mRNA of RNA extracted from left kidneys of 7 normal rats. In each sample, $20 \mu \mathrm{g}$ of total RNA were analyzed. Different lanes represent hybridization signals obtained with different animals. RNA extracted from these kidneys was then pooled and used as standard RNA for the experiments that followed. Molecular size markers were obtained by an Hpa II digest of pBR 322 DNA. Renin (arrow) indicates protected preprorenin fragment. 
found to be not significantly different. There was also no systematic change or side difference of mRNA levels in the kidneys of sham-denervated animals (Figs. $4 A$ and 5 ). In the denervated kidneys (Figs. $4 A$ and 5 ), however, mRNA levels were reduced to $55 \pm 11.6 \%$ (Fig. 5 ) of the standard pooled from normal rats $(P<0.01$ denervated vs. sham-operated rats), whereas the levels in the contralateral innervated kidney were normal $(125 \pm 22.2 \%)$. As a consequence, the ratio of renin mRNA levels between the left and right kidney fell from $1.17 \pm 0.13$ in normal rats and $1.00 \pm 0.17$ in sham-denervated rats to $0.46 \pm 0.07$ in unilaterally denervated animals (Fig. 5) $(P<0.01$ vs. sham-denervated rats). For control we also analyzed the abundance of a housekeeping gene product such as rat cytoplasmic $\beta$-actin mRNA by RNase protection. As shown in Fig. $4 B$, there were no differences in actin mRNA levels between the two kidneys in the rats with unilateral renal denervation.

Because these data indicated that renal innervation influences the expression of renin under basal conditions, we further examined the effect of unilateral denervation on the expression of the renin gene in rats after stimulation. Hypotensive hemorrhage, which is known to be a potent stimulus for the sympathetic nervous system and for the renin-angiotensin system, was utilized for our study. To this end, rats were bled according to the protocol described. Bleeding reduced

A

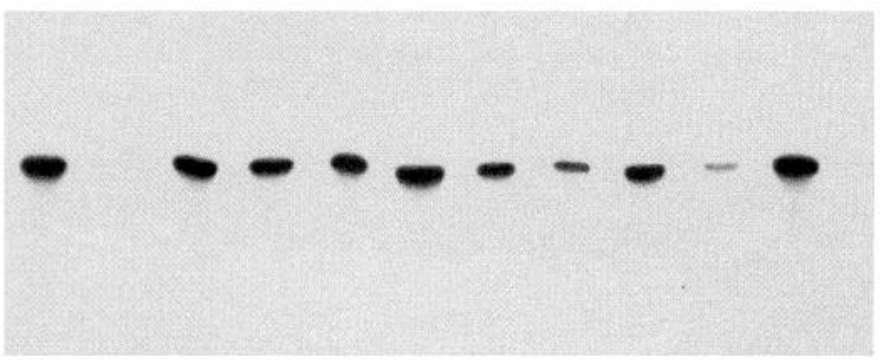

$\vdash$ Sham $\neg \vdash$ Denervation $\dashv$

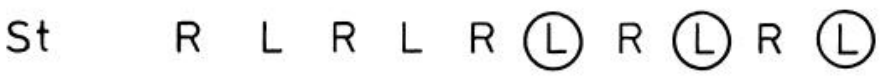

B

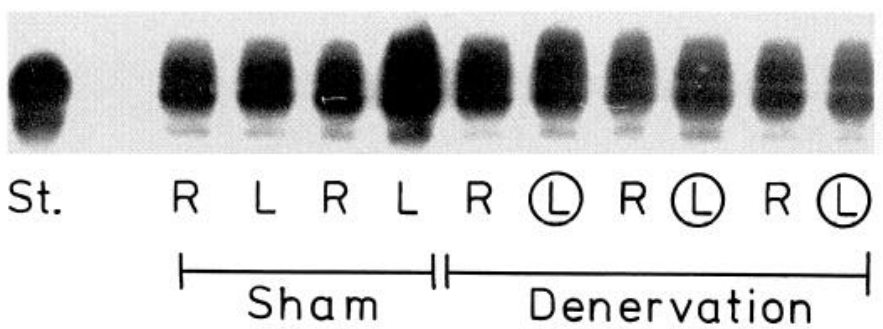

Fig. 4. A: autoradiograph of an RNase protection assay for rat renin mRNA of RNA extracted from right and left kidneys of sham-treated and left-side-denervated rats. In each sample, $20 \mu \mathrm{g}$ of total RNA were analyzed. The standard (St) was prepared as described in Fig. 3 legend. $B$ : autoradiograph of an RNase protection assay for actin mRNA of total RNA extracted from same kidneys as in $A$. In each sample, $2.5 \mu \mathrm{g}$ of total RNA were analyzed.
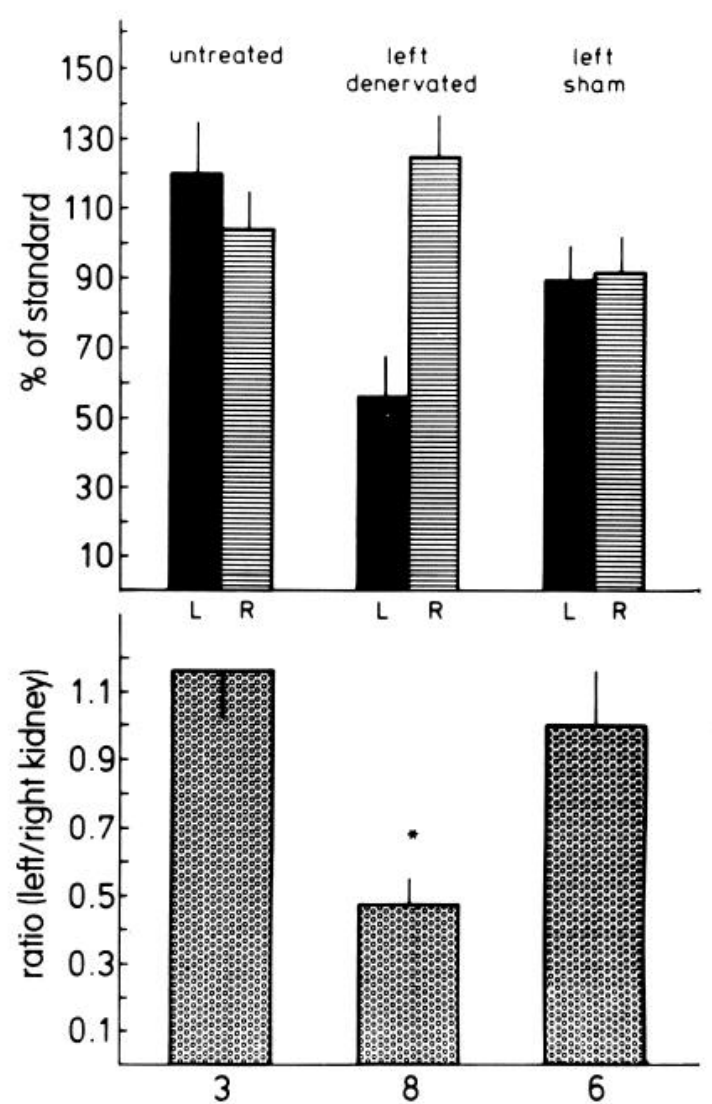

Fig. 5. Top: abundance of renin mRNA in right and left kidneys from untreated, sham-treated, and left-side-denervated rat, expressed as \% of standard RNA. Bottom: ratio of renin mRNA levels between left and right kidneys of individual animals in the different treatment groups. Data are means $\pm \mathrm{SE}$; no. of animals is given at bottom of figure. ${ }^{*} P<$ 0.05 .

the hematocrit to $12.7 \pm 0.8 \%$ (mean $\pm \mathrm{SE} ; n=14$ ) and was associated with a fall of the mean arterial blood pressure from $122 \pm 7 \mathrm{mmHg}$ before to $74 \pm 8 \mathrm{mmHg}$ (mean $\pm \mathrm{SE} ; n=14) 4 \mathrm{~h}$ after the last bleeding (Table 1 ). Animals were killed $4 \mathrm{~h}$ after the last bleeding, and renal RNA was extracted for analysis of renin mRNA levels. Figure $6 A$ shows an autoradiograph of a representative experiment in which kidneys from bled animals were examined. Four hours after bleeding, renin mRNA levels increased by $36 \%$ on average in the kidneys of sham-denervated animals (Fig. 6B, top). Increases to similar levels were observed in the denervated and in the contralateral innervated kidneys of treated animals. Consequently, the ratio of renin mRNA levels between the denervated and the innervated kidney rose from

Table 1. Hematocrit and mean arterial pressure in rats before and after hemorrhage

\begin{tabular}{lcccccc}
\hline \hline & & \multicolumn{2}{c}{ Before Hemorrhage } & & \multicolumn{2}{c}{ After Hemorrhage } \\
\cline { 3 - 4 } \cline { 6 - 7 } & & Het, \% & MAP, $\mathrm{mmHg} n$ & & Het, \% & MAP, mmHg \\
\hline Denervation & 6 & $40.0 \pm 0.9$ & $126 \pm 9$ & & $14 \pm 0.9$ & $80 \pm 8$ \\
Sham & 4 & $38.4 \pm 1.4$ & $120 \pm 3$ & & $10.8 \pm 1.1$ & $61 \pm 10$ \\
B-Blocker & 4 & $38.3 \pm 0.9$ & $117 \pm 7$ & & $12.7 \pm 0.7$ & $78 \pm 9$ \\
\hline
\end{tabular}

Data are means $\pm \mathrm{SE} ; n$, no. of animals. Hct, hematocrit; MAP, mean arterial pressure. 
A

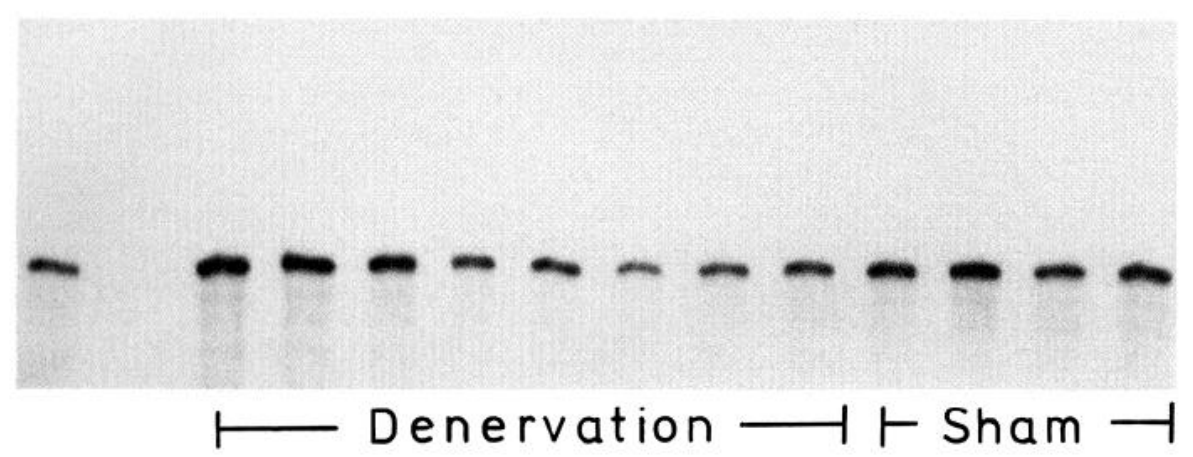

B

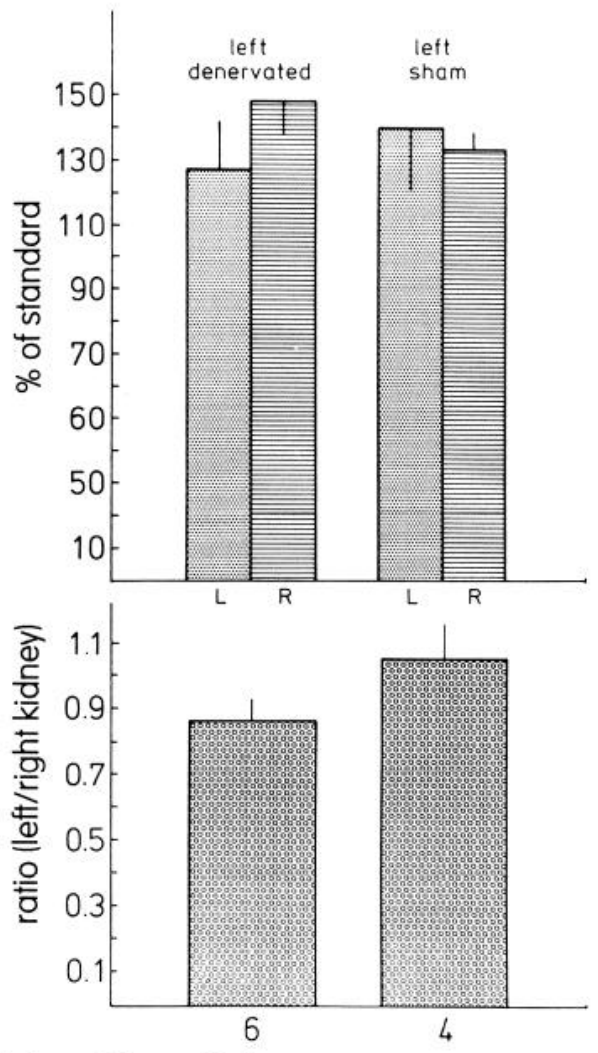

Fig. 6. A: autoradiograph of an RNase protection assay for rat renin mRNA of RNA extracted from right and left kidneys of sham-treated and left-side-denervated rats $4 \mathrm{~h}$ after bleeding. In each sample, $20 \mu \mathrm{g}$ of total RNA were analyzed. $B: t o p$, abundance of renin mRNA in right $(\mathrm{R})$ and left $(\mathrm{L})$ kidneys from untreated, sham-treated, and left-side-denervated rats $4 \mathrm{~h}$ after bleeding, expressed as \% of standard RNA. Bottom, ratio of renin mRNA levels between left and right kidneys of individual animals in the different treatment groups. Data are means $\pm \mathrm{SE}$; no. of animals is given at bottom.

$0.46 \pm 0.07$ in the nonbled to $0.86 \pm 0.07$ in the bled animals and was not different $(P>0.2)$ from that in sham-operated animals in which the ratio between left and right kidney was $1.05 \pm 0.11$ (Fig. 6B, bottom). Obviously, the side difference of renin mRNA levels in the unilaterally denervated animals was markedly blunted in response to hypotensive bleeding, when compared with the nonstimulated state.

Finally, we examined the interrelation between renal nerves and $\beta_{1}$-adrenergic receptors in the control of renal renin gene expression. To this end the $\beta_{1}$-selective adrenergic antagonist metoprolol succinate $(50 \mathrm{mg} / \mathrm{kg}$ twice a day) was administered orally by gavage for 2 days to rats with and without left renal denervation. In the eight kidneys of four rats with intact renal innervation, metoprolol decreased renin mRNA levels in vehicle-fed animals from $105 \pm 5 \%$ (mean $\pm \mathrm{SE}, n=8)$ to $71 \pm 8 \%$ of the standard (Fig. 7). In four animals with left renal denervation fed with metoprolol, renin mRNA levels decreased to $71 \pm 7 \%$ (mean $\pm \mathrm{SE} ; n=4)$ and to $40 \pm 7 \%$ of standard in the right and left kidneys, respectively. The ratio of the abundance of renin mRNA levels found in the left over the right kidney in the individual animals of this group was $0.60 \pm 0.17$ (mean $\pm \mathrm{SE}, n=4)$. Also, four rats treated with metoprolol were subjected to bleeding according to the protocol described (Table 1).

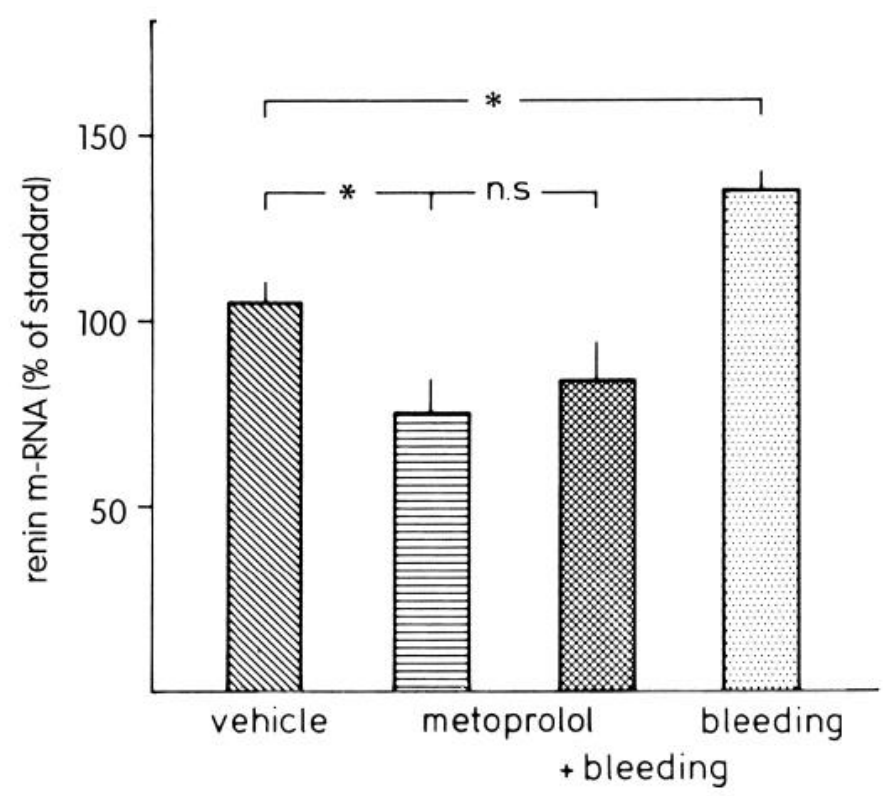

Fig. 7. Abundance of renin mRNA levels expressed as \% of standard RNA in kidneys of vehicle-fed and of metoprolol-fed rats with and without hypotension induced by bleeding. Data are means \pm SE of 8 kidneys each of 4 vehicle-fed, 4 metoprolol-fed, and 4 metoprolol-fed and bled rats. Data for bled control (sham) rats were taken from Fig. 6 and are means $\pm \mathrm{SE}$ of 8 kidneys from 4 rats. ${ }^{*} P<0.05$; NS, not significant. 
As shown in Fig. 7, bleeding did not significantly increase renin mRNA levels in the kidneys of metoprololtreated animals.

\section{DISCUSSION}

This study aimed to investigate the contribution of renal nerves to the control of renin expression in the kidneys of adult rats. Our results show that unilateral denervation leads to an $\sim 50 \%$ decrease of both renin mRNA and kidney areas immunoreactive for renin. Because previous studies have strongly suggested that there is a close relationship between the expression of the renin gene and the renin immunoreactivity in individual juxtaglomerular cells $(7,9)$, and because recruitment and loss of renin gene-expressing cells seems to be an important mechanism regulating the renin production in the kidneys $(8,10)$, on the basis of our findings it appears likely that renal denervation decreased renin mRNA levels by decreasing the number of renin-expressing cells. Inversely, our findings suggest that a steady neural input recruits $\sim 50 \%$ of the cells expressing renin under normal conditions. Consequently, these data indicate that renal nerves are not only important for the expression of the renin gene in the fetus and newborn (17) but also in the adult organism. This conclusion thus confirms the recent demonstration that unilateral renal denervation lowers renin secretion, renin content, and renin mRNA levels in the kidneys of adult mice (21). Selective inhibition of $\beta_{1}$-adrenergic receptors also decreased renal renin mRNA levels by $30 \%$, suggesting that $\beta_{1}$-adrenergic activation also substantially contributes to the basal expression of the renin gene in the kidney of adult rats. This finding fits with the observations that $\beta_{1}$-adrenergic receptors exist on juxtaglomerular cells (15) and that activation of renal $\beta$-adrenergic receptors is a physiologically relevant pathway for stimulation of renin secretion (16, see Ref. 12 for review). Because the effects of denervation and of the $\beta_{1}$-receptor antagonist were not additive, it may be reasonably inferred that $\beta$-receptors mediate, at least in part, the stimulatory role of renal nerves on renin gene expression. The finding that denervation further decreased renin mRNA levels in animals treated with the $\beta$-adrenergic antagonist could have two explanations, which cannot be distinguished by our experiments. Either the rather high dose of metoprolol (100 $\mathrm{mg} \cdot \mathrm{kg}^{-1} \cdot$ day $^{-1}$ ) was not sufficient to effectively block all $\beta_{1}$-receptors, raising the possibility that the stimulatory effect of renal nerves on renin gene expression could be almost exclusively mediated via $\beta$-receptors, or, alternatively, additional transmitters could be involved, such as dopamine or calcitonin gene-related peptide, which have been found to stimulate renin secretion on the level of juxtaglomerular cells $(13,14)$.

Although our findings concerning the temporal effect of denervation on renin mRNA levels are in good agreement with previous studies $(6,7,21)$, it is more difficult to understand how renin-containing areas could decrease by $\sim 50 \%$ within 5 days after denervation, in view of a basal renin secretion rate that has been estimated to be $\sim 1 \%$ of the total renin content (19). A similar phenomenon was recently reported for adult mice, in which renal denervation decreased renin mRNA by $60 \%$ and renin content by $40 \%$ within 7 days, whereas renin secretion from the denervated kidneys was almost blunted (21). This could indicate that renin secretion into the circulation is not the only pathway along which renin can disappear from the kidneys. One could speculate, therefore, that intrarenal degradation of renin could also contribute to the disappearance of renin from denervated kidneys.

It was shown recently that in newborn animals renal nerves essentially mediate the stimulation of renin gene expression in response to unilateral ureteral occlusion (6). In that study the effect of denervation by a chemical (guanethidine treatment) and a mechanical protocol was significant in a condition that leads to an increase in renin biosynthesis. Furthermore, an important role of the renal nerves in regulating stimulated renin gene expression and renin secretion was seen in newborn lambs during transition from the fetal to the newborn state (17). For adult organisms as well, good evidence exists that renal nerves and renal $\beta_{1}$-adrenergic receptors mediate stimulations of renin secretion $(12,16)$. The role of innervation and of $\beta$-receptors for renin gene expression in the adult kidney under stimulated conditions is to our knowledge yet unknown. One pathophysiological situation relevant in this context is severe blood loss, which leads to a fall of blood pressure and to volume contraction, both of which cause sympathetic nerve stimulation and both of which are counteracted by an activation of the renin-angiotensin system. Our findings show that at $4 \mathrm{~h}$ after induction of hypotension by bleeding there was already a significant increase of renin mRNA levels in the kidneys. Interestingly, mRNA levels in both innervated and denervated kidneys increased to nearly the same level in the hypotensive animals. One may infer, therefore, that stimulation of renin gene expression in response to severe hemorrhage was not essentially mediated by renal nerves.

Because the increase of renin mRNA levels in response to hemorrhage was blunted by a $\beta_{1}$-adrenergic antagonist, it appears likely that the stimulation of renin gene expression in this situation was primarily mediated by circulating catecholamines.

Considering the fact that renin mRNA levels increased in response to hypotensive bleeding to a markedly larger extent in denervated kidneys than in innervated kidneys, one may infer that denervated kidneys are particularly sensitive to circulating catecholamines, which might indicate an upregulation of $\beta$-adrenergic receptors in the denervated kidneys.

Finally, we wish to emphasize that our findings do not rule out a possible regulatory role of renal nerves for renin gene expression in cases of more moderate nonhypotensive blood losses. In fact, it has been found that nonhypotensive hemorrhage stimulates renin secretion via nerves (see Ref. 12 for review). In view of the delay and the small amplitude of the changes of renal renin mRNA even in response to severe hypotensive hemorrhage, however, our experimental protocol appeared less 
well-suited to assess changes in renin mRNA levels in response to mild hemorrhage.

Taken together, our findings suggest that renal nerves substantially contribute to the basal expression of the renin gene in the kidney. At least part, if not all, of this effect is mediated via $\beta_{1}$-adrenergic receptors. Catecholamines, but not renal nerves, appear to be essentially involved in the stimulation of renin gene expression in response to hypotensive hemorrhage.

We thank $R$. Metzger for providing us with the rat preprorenin cDNA, P. Ratcliffe for providing us with rat $\beta$-actin cDNA, and T. Inagami for the generous gift of the renin antiserum. Metoprolol succinate was kindly provided by Astra Chem, Wedel, Germany. The expert technical and graphical assistance provided by K. H. Götz, M. Hamann, and U. Holzapfel and the secretarial help provided by $\mathrm{H}$. Trommer are gratefully acknowledged.

This study was financially supported by a grant from the Deutsche Forschungsgemeinschaft (Az. Ku 859/2-1).

Address for reprint requests: A. Kurtz, Institute of Physiology, University of Regensburg, PO Box 101042, Universitätsstr. 31, D-93040 Regensburg, Germany.

Received 13 August 1993; accepted in final form 17 November 1993.

\section{REFERENCES}

1. Bello-Reuss, E., R. E. Colindres, E. Pastoriza-Munoz, R. A. Mueller, and C. W. Gottschalk. Effects of acute unilateral renal denervation in the rat. J. Clin. Invest. 56: 208-217, 1975.

2. Burnham, C. E., C. L. Hawelu-Johnson, B. M. Frank, and K. R. Lynch. Molecular cloning of rat renin cDNA and its gene. Proc. Natl. Acad. Sci. USA 84: 5605-5609, 1987.

3. Chirgwin, J. M., A. E. Przybla, R. J. MacDonald, and W. J. Rutter. Isolation of biologically active ribonucleic acid from sources enriched for ribonucleases. Biochemistry 18: 5294-5299, 1979.

4. Dawson, T., R. Gandhi, M. Le Hir, and B. Kaissling. Ecto-5'-nucleotidase: localization in rat kidney by light microscopic histochemical and immunohistochemical methods. J. Histochem. Cytochem. 37: 39-47, 1989.

5. Eckardt, K.-U., M. Le Hir, C. C. Tan, P. J. Ratcliffe, B. Kaissling, and A. Kurtz. Renal innervation plays no role in oxygen-dependent control of erythropoietin mRNA levels. Am.J. Physiol. 263 (Renal Fluid Electrolyte Physiol. 32): F925-F930, 1992.

6. El-Dahr, S. S., R. A. Gomez, M. S. Gray, M. J. Peach, R. M. Carey, and R. L. Chevalier. Renal nerves modulate renin gene expression in the developing rat kidney with ureteral obstruction. J. Clin. Invest. 87: 800-810, 1991.

7. Gomez, R. A., K. R. Lynch, R. L. Chevalier, N. Wilfong, A. Everett, R. M. Carey, and M. J. Peach. Renin and angiotensinogen gene expression in maturing rat kidney. Am. J. Physiol. 254 (Renal Fluid Electrolyte Physiol. 23): F583-F587, 1988.

8. Gomez, R. A., K. R. Lynch, R. L. Chevalier, A. D. Everett, D. W. Johns, N. Wilfong, M. J. Peach, and R. M. Carey. Renin and angiotensinogen gene expression and intrarenal renin distribution during ACE inhibition. Am. J. Physiol. 254 (Renal Fluid Electrolyle Physiol. 23): F900-F906, 1988.

9. Gomez, R. A., K. R. Lynch, B. C. Sturgill, J. P. Elwood, R. L. Chevalier, R. M. Carey, and M. J. Peach. Distribution of renin mRNA and its protein in the developing kidney. Am. J. Physiol. 257 (Renal Fluid Electrolyte Physiol. 26): F850-F858, 1989.

10. Gomez, R. A., R. L. Chevalier, A. D. Everett, J. P. Elwood, M. J. Peach, K. R. Lynch, and R. M. Carey. Recruitment of renin gene-expressing cells in adult rat kidneys. Am. J. Physiol. 259 (Renal Fluid Electrolyte Physiol. 28): F660-F665, 1990.

11. Karnowsky, M. J. The localization of cholinesterase activity in rat cardiac muscle by electron microscopy. J. Cell Biol. 23: $217-232,1964$.

12. Keeton, T. K., and W. B. Campbell. The pharmacologic alteration of renin release. Pharmacol. Rev. 31: 81-227, 1981.

13. Kurtz, A., R. Della Bruna, J. Pratz, and I. Cavero. Rat juxtaglomerular cells are endowed with DA-1 dopamine receptors mediating renin release. J. Cardiovasc. Pharmacol. 12: 658-663, 1988.

14. Kurtz, A., R. Muff, W. Born, J. M. Lundberg, B. I. Millberg, M. P. Gnädinger, D. E. Uehlinger, P. Weidmann, T. Hökfelt, and $J$. A. Fischer. Calcitonin gene-related peptide is a stimulator of renin secretion. J. Clin. Invest. 82: 538-543, 1988.

15. Lew, R., and R. J. Summers. Autoradiographic localization of beta-adrenoreceptor subtypes in guinea-pig kidney. Br. J. Pharmacol. 85: 341-348, 1985.

16. Osborn, J. L., G. F. DiBona, and M. D. Thames. Beta-1 receptor mediation of renin secretion elicited by low frequency renal nerve stimulation. J. Pharmacol. Exp. Ther. 216: 265-269, 1981.

17. Page, W. V., S. Perlman, F. G. Smith, J. L. Segar, and J. E. Robillard. Renal nerves modulate kidney renin gene expression during the transition from fetal to newborn life. Am. J. Physiol. 262 (Renal Fluid Electrolyte Physiol. 31): R459-R463, 1992.

18. Ratcliffe, P. J., R. W. Jones, R. E. Phillips, L. G. Nicholls, and J. I. Bell. Oxygen-dependent modulation of erythropoietin mRNA levels in isolated rat kidneys studied by RNase protection. J. Exp. Med. 172: 657-660, 1990.

19. Taugner, R., and E. Hackenthal. The Juxtaglomerular Apparatus. Berlin: Springer-Verlag, 1989.

20. Weibel, E. R. Stereological methods. In: Practical Methods for Morphometry. New York: Academic, 1979, vol. 1.

21. Zhang, Y., T. Morgan, and G. Read. The role of the renal nerves in renin synthesis. Clin. Exp. Pharmacol. Physiol. 19: 827-831, 1992. 